2. Галкина Е. Н. Терминология Европейского Союза и проблемы ее перевода на русский язик. Дис. канд. филол. наук. М., 1998. 318 с.

3. Гринев-Гриневич С.В. Терминоведение. М., 2008. 301 с.

4. Дерді Е.Т. Омонімія в англійській юридичній термінології. Ужгород, 2001. С. 54-58.

5. Суперанская А.В., Подольская Н.В., Васильева Н.В. Общая терминология: Вопросы теории. М.: Наука, 1989. - 243 с.

DOI https://doi.org/10.30525/978-9934-26-073-5-1-64

\title{
КОМУНІКАТИВНА СТРУКТУРА ПОЛІПРЕДИКАТИВНИХ СКЛАДНОПІДРЯДНИХ РЕЧЕНЬ З ОКРЕМИМИ ЛАНКАМИ ТЕМА-РЕМАТИЧНИХ ВІДНОШЕНЬ В АНГЛОМОВНІЙ ХУДОЖНІЙ ПРОЗІ
}

\author{
Панькова Т. В. \\ кандидат філологічних наук, \\ асистент кафедри англійської філології \\ Прикарпатського національного університету \\ імені Василя Стефаника \\ м. Івано-Франківськ, Украӥна
}

У сучасних синтаксичних студіях поліпредикативні складнопідрядні речення (далі - ППСПР) розглядаються як конструкції, у яких поєднуються 2-3 різновиди підрядності. Становлячи у формально-граматичному плані поліпредикативну конструкцію, компоненти якої знаходяться в певних структурно-семантичних зв'язках, завдяки інтенції мовця ППСПР - це синтаксична одиниця, яка характеризується цілісністю комунікативної організації.

Завдяки комунікативній спрямованості гіпотактичної конструкції складнопідрядне речення (далі - СПР) $є$ «замкненим комунікативним простором» [1, с. 144], у якому актуальне членування (далі - АЧ) здійснюється як єдиний акт членування інформації. Концептуально закладена особливість семантики СПР визначає й принципово інші (у порівнянні з монопредикативним реченням) комунікативні реалії. Тут фактор АЧ проявляється більш яскраво, а семантична неоднорідність СПР зумовлює комунікативну неоднорідність інформації, що в ньому міститься [там само, с. 193]. Це, у свою чергу, зумовлює багатоступеневий характер АЧ ППСПР. 
На думку Т. І. Кормановської, такий багатоступеневий характер АЧ СПР «цілком гармонійно поєднується 3 його одноплановою функціональною перспективою, що підкреслює поступовий рух компонентів інформаційної структури, лінійне розгортання мовлення» [2, c. 103-104].

Урахування принципу багаторівневості уможливлює виокремлення чотирьох основних комунікативних типів досліджуваних конструкцій:

1) з комплексною темою;

2) 3 комплексною ремою;

3) з комплексною темою і ремою;

4) з окремими ланками тема-рематичних відношень.

Серед найбільш поширених моделей комунікативного типу ППСПР 3 окремими ланками тема-рематичних відношень найбільш часто зустрічаються моделі з:

a) неоднорідною супідрядністю:

(1) Every morning before I was out the main gate I had one last impression that was both ordinary and unforgettable <...>. (Martel, LP) Див. Схему ${ }^{4}$ :

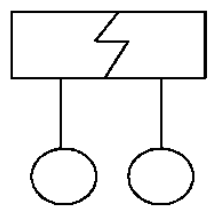

б) неоднорідною супідрядністю і послідовною підрядністю:

(2) A chance meeting with someone who knew of his grandfather's mania made him realize that it was only in the family that the old man's endless days of supervising bewildered gangs of digging rustics were regarded as a joke. (Fowles, FLW) Див. схему:

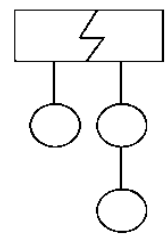

${ }^{1}$ Прямокутник позначає головну предикативну одиницю, коло - підрядну, а ламана лінія всередині прямокутника - розрив головної предикативної одиниці на дві частини 
в) послідовною підрядністю, неоднорідною супідрядністю i послідовною підрядністю:

(3) If I had considered the matter when we were young I think I would have said that the basic spiritual principle of James's life was an avoidance of vulgarity. (Murdoch, SS)

(4) Whenever any of his old friends began to suggest that her acting had some depth, or charm, or special merit, he silently nurtured the atrocity, reminding himself that nobody but he could know how shallow she really was. (Spark, PI) Див. схему:

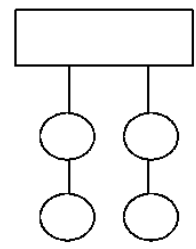

Прикладом структури 3 окремими ланками тема-рематичних відношень може служити наступна поліпредикативна конструкція:

(5) Meanwhile the third man, who has been baling out the boat, and who has spilled the water down his sleeve, and has been cursing away to himself steadily for the last ten minutes, wants to know what the thundering blazes you're playing at, and why the blarmed tent isn't up yet. (Jerome, TMВ) Див. схему:

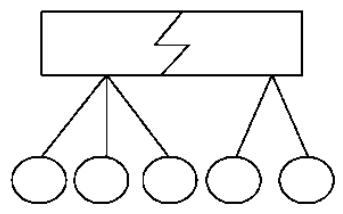

Наведене вище ППСПР складається 3 п’яти предикативних одиниць 3 різночленною неоднорідною супідрядністю, однорідною супідрядністю й послідовною підрядністю. Темою речення виступає частина головної предикативної одиниці із блоком залежних атрибутивних предикативних одиниць (Meanwhile the third man, who has been baling out the boat, and who has spilled the water down his sleeve, and has been cursing away to himself steadily for the last ten minutes), а ремою - залишкова частина головної предикативної одиниці із залежними супідрядними частинами 3 об'єктно-з'ясувальною семантикою. 
Схема АЧ цього речення має наступний вигляд:

$\mathrm{T}\left(\mathrm{T}_{1}-\mathrm{T}_{2}-\mathrm{T}_{3}\right)-\mathrm{R}\left(\mathrm{R}_{1}-\mathrm{R}_{2}-\mathrm{R}_{3}\right)$,

де $\mathrm{T}$ - Meanwhile the third man, who has been baling out the boat, and who has spilled the water down his sleeve, and has been cursing away to himself steadily for the last ten minutes, $\mathrm{T}_{1}$ - the third man, $\mathrm{T}_{2}-$ who has been baling out the boat, $\mathrm{T}_{3}$ - who has spilled the water down his sleeve and has been cursing away to himself steadily for the last ten minutes; $\mathrm{R}$ - wants to know what the thundering blazes you're playing at, and why the blarmed tent isn't up yet, $R_{1}$ - wants to know, $R_{2}$ - what the thundering blazes you are playing at i $R_{3}$ - why the blarmed tent isn't up yet.

За частотністю уживання в англомовній художній прозі комунікативні типи досліджуваних конструкцій складають 7,4 \%.

\section{Література:}

1. Абашина В.Н. Вопросы коммуникативно-прагматического описания сложного предложения в русском языке: аспект актуального членения. Львов: Издательский центр ЛНУ им. И. Франко, 2006. 344 с.

2. Кормановская Т. И. О комунникативной организации сложноподчиненного предложения (на материале английского языка). Bonpocbl языкознания. 1987. № 2. С. 102-110.

\section{Джерела ілюстративного матеріалу:}

1. (Fowles, FLW) Fowles John. The French Lieutenant's Woman. URL: file:///C:/Users/USER/Downloads/The\%20French\%20Lieutenant\% E2\%80\%99s\%20Woman.pdf (дата звернення: 10.05.2019).

2. (Jerome, TMB) Jerome K. Jerome. ThreeMeninaBoat. URL: http://people.apache.org/ lfurini/wiki/book.standard.pdf (дата звернення: 10.05.2019).

3. (Martel, LP) Martel Yann. The Life of Pi. URL : https://royallib.com/ read/martel_yann/Life_of_Pi.html\#0 (дата звернення: 10.05.2019).

4. (Murdoch SS) Murdoch Iris. The Sea, the Sea. URL: https://royallib.com/read/Murdoch_Iris/The_Sea_the_Sea.html\#0 (дата звернення: 10.05.2019).

5. (Spark, PI) Spark Muriel. The Public Image. London : Penguin Books, 1968. $125 \mathrm{p}$. 